\title{
Jumlah Uang Beredar, Nilai Tukar Perdagangan Luar Negeri Dan Inflasi Di Indonesia
}

\author{
Edalmen \\ Fakultas Ekonomi Universitas Tarumanagara Jakarta \\ Email:edalmen@fe.untar.ac.id
}

\begin{abstract}
This study aims to determine the effect of the money supply and the exchange rate of foreign trade on inflation in Indonesia. This study concludes that the money supply has a positive and significant influence on inflation. The foreign trade exchange rate has a negative relationship to inflation, but the effect is not statistically significant. For further research it is recommended to add other independent variables that are related and take into account the exchange rate of foreign trade according to the group of goods.
\end{abstract}

Keywords: Money Supply, Exchange Rate of Foreign Trade, Consumer Price Index, Inflation

\begin{abstract}
Abstrak: Penelitian ini bertujuan untuk mengetahui pengaruh jumlah uang beredar dan nilai tukar perdagangan luar negeri terhadap inflasi di Indonesia. Penelitian ini menyimpulkan bahwa jumlah uang beredar mempunyai pengaruh positif dan signifikan terhadap inflasi. Adapun nilai tukar perdagangan luar negeri mempunyai hubungan negatif terhadap inflasi, akan tetapi pengaruhnya tidaklah signifikan secara statistik. Untuk penelitian lanjutan disarankan untuk menambah variabel bebas lain yang berkaitan dan memperhitungkan nilai tukar perdagangan luar negeri menurut kelompok barang.
\end{abstract}

Kata Kunci: Jumlah Uang Beredar, Nilai Tukar Perdagangan Luar Negeri, Indek Harga Konsumen, Inflasi.

\section{PENDAHULUAN}

Tujuan pembangunan Indonesia adalah untuk mencapai masyarakat adil dan makmur. Pembangunan di bidang ekonomi dapat menyediakan sumber sumber pembangunan yang lebih luas dibidang bidang lainnya, oleh karena itu pembangunan di bidang ekonomi dapat dikatakan sebagai landasan yang kuat bagi suatu negara untuk melaksanakan pembangunan selanjutnya. Salah satu landasan utama ekonomi setiap negara adalah tercapainya stabilitas harga, untuk itu diperlukan berbagai kebijakan strategis yang dilakukan secara komprehensif dengan beberapa sasaran jangka pendek dan jangka panjang.

Perkembangan tingkat harga atau inflasi merupakan salah satu masalah ekonomi makro yang perlu mendapat perhatian guna menjaga stabilitas perekonomian suatu negara. Sedangkan stabilitas merupakan syarat pokok bagi usaha pembangunan yang berkesinambungan. Indonesia pernah mengalami masa masa berat dalam perekonomiannya yang disebabkan oleh sangat tingginya laju inflasi, sehingga tidaklah begitu mengherankan pemerintah beberapa tahun terakhir ini benar benar berupaya untuk menekan laju inflasi dengan berbagai cara agar agar tidak melebihi 10 persen pertahun (double digit inflation). 
Bagi negara yang sedang membangun seperti Indonesia untuk mencegah inflasi sama sekali tidaklah mungkin. Karena inflasi yang relatif rendah atau inflasi merangkak dipercayai akan dapat merangsang kegiatan investasi sehingga terjadi pertumbuhan ekonomi yang relatif tinggi tanpa menimbulkan ketidakseimbangan yang mengganggu stabilitas ekonomi.

Masalah yang paling rumit mengenai inflasi adalah hal yang berkaitan dengan upaya pengendaliannya. Hal ini tergantung kepada pemahaman mengenai faktor faktor dan proses penyebab timbulnya inflasi. Berdasarkan data yang diolah dari Badan Pusat Statistik terlihat perkembangan inflasi yang cukup tinggi selama dua dasawarsa terakhir ini. Dengan indek (tahun 2000=100), Indek Harga Konsumen meningkat dari hanya 28,51 pada tahun 1990 menjadi 243,46 pada tahun 2012. Inflasi tertinggi terjadi pada tahun 1998 dengan tingkat inflasi 77,63 persen sebagai akibat dari krisis moneter di akhir rezim orde baru. Sementara itu inflasi yang rendah terjadi pada tahun 1999 dan 2009. Tetapi hal yang perlu diperhatikan adalah rendahnya inflasi pada tahun tahun tersebut disebabkan oleh tingginya tingkat inflasi pada tahun sebelumnya.

Fluktuasi turun naiknya tingkat inflasi tersebut tentu disebabkan oleh banyak faktor yang terkait dalam pembentukan tingkat harga itu sendiri. Berbagai teori mengenai inflasi telah dikembangkan oleh para ahli ekonomi untuk menjelaskan gejala kenaikan harga harga ini. Menurut golongan moneteris, jumlah uang beredar merupakan faktor penting yang mempengaruhi tingkat harga. Jika kita perhatikan perkembangan jumlah uang beredar dalam periode yang sama memang cenderung memperkuat pandapat tersebut. Tetapi belum diketahui seberapa jauh pengaruh jumlah uang beredar tersebut terhadap inflasi.

Disamping itu selain faktor yang berasal dari dalam negeri kenaikan tingkat harga umum juga dapat terjadi oleh faktor faktor yang berasal dari luar negeri. Inflasi ini akan lebih mudah terjadi bagi negara yang menganut sistem perekonomian terbuka sebagai akibat perubahan dalam harga ekspor ataupun harga impor.

Indonesia adalah sebuah negara berkembang yang dalam kegiatan pembangunan peranan pemerintah adalah sangat penting, terutama dalam hal pembiayaan pembangunan serta kegiatan dan aktifitas ekonomi secara global. Untuk itu diperlukan banyak dana agar pembangunan dan pertumbuhan ekonomi dapat berjalan sesuai dengan yang diharapkan. Dana tersebut dapat diperoleh dari dalam maupun luar negeri yang pada akhirnya akan mempengaruhi perkembangan jumlah uang beredar didalam negeri. Tetapi apabila jumlah uang beredar terlalu banyak sehingga melebihi permintaan akan uang dapat menyebabkan kenaikan harga atau inflasi.

Selain itu sebagai negara yang menganut sistem perekonomian terbuka, terdapat beberapa kemungkinan timbulnya pengaruh yang cukup besar dalam perekonomian Indonesia. Keterbukaan perekonomian Indonesia tercermin dari tingginya rasio perdagangan luar negeri terhadap produksi nasional, baik untuk ekspor maupun impor. Sehingga perkembangan tingkat harga ekspor dan impor tersebut mempunyai peranan yang cukup berarti bagi pembentukan tingkat harga secara umum di dalam negeri. Sehubungan dengan uraian tersebut, maka penulis merasa tertarik untuk melakukan penelitian ini lebih jauh dengan judul "Perkembangan Jumlah Uang Beredar dan Nilai Tukar Perdagangan Luar Negeri serta Pengaruhnya Terhadap Inflasi di Indonesia"

Dalam penelitian ini faktor yang akan diteliti lebih dibatasi kepada dua hal yaitu: (1) Pengaruh Jumlah Uang Beredar (JUB) terhadap Inflasi yang diukur dengan perkembangan indeks harga konsumen (IHK) di Indonesia; (2) Pengaruh Nilai Tukar 
Perdagangan Luar Negeri ( NTP ) terhadap inflasi yang diukur dengan perkembangan indeks harga konsumen (IHK) di Indonesia

Berdasarkan latar belakang serta batasan masalah diatas, dalam penelitian ini diajukan masalah seperti berikut : Seberapa besar pengaruh serta kontribusi Jumlah uang Beredar (JUB) dan Nilai Tukar Perdagangan Luar Negeri (NTP) baik secara parsial maupun secara bersama-sama terhadap Inflasi yang diukur dengan perkembangan indeks harga konsumen (IHK) di Indonesia?

\section{KAJIAN TEORI}

Pengertian Inflasi. Sebetulnya tidak ada definisi yang memuaskan dan dapat diterima secara umum. (Samuelson, 2006) menyatakan bahwa inflasi adalah suatu masa kenaikan harga harga barang dan faktor faktor produksi. Sebuah Artikel di dalam Encyclopaedia of Social Science mendefinisikan inflasi seperti sering diartikan oleh para ahli ekonomi waktu itu, sebagai naiknya tingkat harga yang disertai dampak negatif bagi masyarakat berupa tekanan terhadap taraf hidup. Akan tetapi kemudian para ahli ekonomi mengartikannya sebagai naiknya tingkat harga umum secara terus menerus (Lipsey, 2004)

(Mankiw, 2006) mendefinisikan inflasi sebagai kecenderungan harga - harga untuk menaik secara umum dan terus menerus. Definisi inflasi yang lebih umum dinyatakan oleh Venieris dan Sebold, seperti dikutip oleh (Gunawan, 1995) yang mendefinisikan inflasi sebagai "a sustained tendency for the general level of price to rise over time". Kenaikan harga yang terjadi sekali waktu saja menurut definisi ini tidak dapat dikatakan sebagai inflasi.

Dari semua definisi diatas dapat dikatakan bahwa inflasi yang terjadi mencakup 3 aspek yaitu: (a) Adanya kecenderungan (tendency) harga harga untuk meningkat, yang berarti mungkin saja tingkat harga yang terjadi pada waktu tertentu turun atau naik dibandingkan dengan waktu yang sebelumnya, tetapi tetap menunjukkan kecenderungan meningkat; (b) Peningkatan harga tersebut berlangsung terus menerus (sustained) yang berarti bukan hanya terjadi pada satu waktu saja; (c) Mencakup pengertian tingkat harga umum (general level of prices) yang berarti tingkat harga yang meningkat itu bukan hanya pada satu atau beberapa komoditi saja

Klasifikasi Inflasi. Berbagai macam cara digunakan oleh para ahli di dalam mengklasifikasikan inflasi ini sesuai dengan tujuan yang diinginkan.Penggolongan pertama didasarkan atas "parah" atau tidaknya inflasi tersebut (Boediono, 1998), dimana inflasi dibedakan atas beberapa macam :

1. Inflasi ringan (dibawah $10 \%$ pertahun)

2. Inflasi sedang (antara $10-30 \%$ pertahun)

3. Inflasi berat (anatara $30-100 \%$ setahun)

4. Hyperinflasi (diatas $100 \%$ )

Sebenarnya penggolongan parah atau tidaknya inflasi ini sangat tergantung kepada kondisi perekonomian negara yang bersangkutan, mungkin saja inflasi yang tergolong parah di suatu negara belum termasuk yang mengkhawatirkan bagi negara lain.

Penggolongan kedua adalah atas dasar sebab awal terjadinya inflasi yang dapat dijelaskan sebagai berikut (Sukirno, 2004).

1. Demand pull inflation. Demand pull inflation disebabkan oleh permintaan total masyarakat akan barang - barang (agregate demand) bertambah. Inflasi ini biasanya 
terjadi pada masa perekonomian yang berkembang dengan pesat. Kesempatan kerja yang tinggi menciptakan tingkat pendapatan yang tinggi dan selajutnya menimbulkan pengeluaran yang melebihi kemampuan ekonomi mengeluarkan barang dan jasa. Pengeluaran yang berlebihan ini akan menimbulkan inflasi.

2. Cost push inflation. Cost push inflation terjadi karena kenaikan biaya produksi, yang disebabkan oleh terdepresinya nilai tukar, dampak inflasi luar negeri terutama negara negara partner dagang, peningkatan harga harga komoditi yang diatur pemerintah dan terjadinya negative supply shocks akibat bencana alam dan terganggunya distribusi.. Semua hal tersebut mengakibatkan biaya - biaya produksi meningkat, yang pada gilirannya menyebabkan kenaikan harga - harga barang.

Penggolongan ketiga dari inflasi didasarkan atas asal dari inflasi tersebut untuk itu inflasi dibedakan atas dua macam:

1. Inflasi yang berasal dari dalam negeri (domestic inflation). Misalnya karena defisit anggaran belanja yang dibiayai dengan mencetak uang baru, atau karena panenan yang gagal dan lain sebagainya

2. Inflasi yang berasal dari luar negeri (imported inflation). Inflasi ini timbul karena adanya kenaikan harga atau atau inflasi di luar negeri atau negara mitra dagang. Gejolak harga komoditi impor maupun ekspor di pasaran dunia akan turut mempengaruhi besarnya tingkat harga umum di dalam negeri.

Berkaitan dengan hal diatas Ichiro Otani seperti yang dikutip (Gunawan, 1995) menyatakan bahwa inflasi yang diimpor dapat terjadinya karena adanya peningkatan harga eskpor maupun impor di pasaran dunia. Peningkatan harga impor akan dapat mempengaruhi tingkat harga umum melalui tiga saluran, yaitu pertama, secara langsung meningkatkan indeks harga umum; kedua melalui peningkatan biaya input bahan baku dan barang modal sehingga mendorong kanaikkan harga, dan ketiga melalui peningkatan pengeluaran impor yang berarti saldo naraca berjalan turun sehingga jumlah uang primer pun turun. Akibatnya terjadi kontraksi jumlah uang beredar akibat peningkatan eskpor. Penularan inflasi dari luar negeri ke dalam negeri ini akan lebih mudah terjadi pada negara negara yang menganut sistem perekonomian yang terbuka, dimana sektor perdagangan luar negerinya sangat penting seperti halnya Indonesia.

Teori Teori Inflasi. Teori yang menerangkan tentang proses terjadinya inflasi secara garis besar dapat digolongkan atas tiga kelompok (Boediono, 1998), masing masingnya bukanlah teori inflasi yang lengkap yang mencakup semua aspek penting dari proses kenaikkan harga. Teori teori tersebut antara lain:

1.Teori Kuantitas.Teori ini merupakan teori yang paling tua mengenai inflasi. Teori ini menyoroti peranan dalam proses inflasi dari jumlah uang yang beredar dan psikologi (harapan) masyarakat mengenai kenaikan harga. Irving Fisher memformulasikan hal ini dalam persamaan sebagai berikut:

$$
\mathrm{M} . \mathrm{V}=\mathrm{P} . \mathrm{T}
$$

dimana:

$\mathrm{M}=$ Jumlah uang yang beredar; $\mathrm{V}=$ Velositas (perputaran) rata rata dari sirkulasi uang dalam satu periode, biasanya satu tahun; $\mathrm{P}=$ Tingkat harga rata rata; $\mathrm{T}=$ Jumlah transaksi yang terjadi dalam satu tahun

Dari persamaan diatas dapat disimpulkan bahwa nilai dari barang barang yang terjual adalah jumlah transaski yang dilakukan, dikalikan dengan tingkat harga rata rata (P.T) dan jumlah ini sama dengan jumlah uang berdar dikalikan dengan Velositas (M.V). 
Dengan asumsi bahwa perubahan velositas sangat lambat dan dalam jangka pendek (V) dianggap konstan dan jumlah transaksi (T) juga konstan, maka berlaku apa yang dikatan oleh teori kuantitas uang bahwa perubahan jumlah uang beredar (M) mengakibatkan perubahan tingkat harga rata rata $(\mathrm{P})$ secara proporsional.

2.Teori Keynes. Teori Keynes ini membahas inflasi atas dasar teori makronya dengan menyoroti aspek lain dari inflasi. Menurut teori ini inflasi terjadi karena sekelompok masyarakat ingin hidup diluar batas kemampuan ekonominya. Hal ini mengakibatkan terjadinya proses perebutan rezeki diantara kelompok kelompok sosial yang menginginkan bagian yang lebih besar dari pada yang bisa disediakan masyarakat, sehingga permintaan atas barang barang melebihi yang tersedia, proses inilah yang sering dinamakan disebut dengan istilah inflationary ga.

3. Teori Strukturalis. Teori strukturalis berpendapat, bahwa penyebab - penyebab inflasi itu berkaitan dengan struktur negara - negara yang sedang berkembang tertentu yang menyebabkan negara tersebut rentan terhadap inflasi. Oleh karena itu dibutuhkan suatu kebijakan yang ditujukan untuk menghapuskan berbagai hambatan struktural yang mengawali dan mengekalkan inflasi itu. Sehubungan dengan itu Canavesse menyatakan bahwa teori inflasi model srukturalis menekankan pada hubungan yang terjadi antara perubahan harga relatif dan kenaikan tingkat harga umum dimana perubahan dalam harga relatif merupakan hasil dari perubahan struktur ekonomi.

Teori strukturalis ini didasarkan pada pengalaman negara - negara Amerika Latin. Teori ini memberikan tekanan pada ketegaran (inflexibilities) dari struktur perekonomian negara - negara sedang berkembang. Menurut terori ini ada dua ketegaran utama dalam perekonomian yang bisa menimbulkan inflasi (Boediono, 1998).

Ketegaran pertama, berupa ketidakelastisan penerimaan ekspor, yaitu nilai ekspor yang tumbuh secara lamban dibandingkan dengan pertumbuhan sektor lain. Kelambanaan ini disebakan karena (a). Harga di pasar dunia dari barang - barang ekspor tersebut makin tidak menguntungkan dibandingkan dengan harga - harga impor yang harus dibayar, atau dikenal dengan terms of trade yang semakin memburuk. (b). Penawaran atau produksi barang barang ekspor yang tidak responsif terhadap kenaikan harga (supply barang barang ekspor tidak elastis). Kelambanan pertumbuhan penerimaan ekspor ini berarti kelambanan pertumbuhan kemampuan untuk mengimpor barang barang yang dibutuhkan baik untuk konsumsi maupun investasi. Akibatnya negara tersebut berusaha mengambil kebijakan dengan menggalakkan produksi dalam negeri dari barang - barang yang sebelumnya diimpor (substitusi impor), meskipun seringkali ongkos produksi dalam negeri ini lebih tinggi dari pada barang sejenis yang diimpor. Keadaan ini semakin meluas dan menimbulkan harga yang lebih tinggi, kenaikan ongkos produksi juga meluas ke barbagai barang yang diimpor, sehingga makin banyak harga yang meningkat.

Ketegaran yang kedua, berkaitan dengan ketidakelastisan dari supply atau produksi bahan makanan di dalam negeri. Dikatakan bahwa produksi makanan di dalam negeri tidak tumbuh secepat pertambahan jumlah penduduk dan penghasilan perkapita, sehingga harga bahan makanan di dalam negeri cenderung untuk menaik melebihi kenaikan harga barang barang ainnnya. Akibatnya adalah timbulnya tuntutan kenaikan tingkat upah disektor industri yang berarti pula kenaikan ongkos produksi dan harga. 
Jumlah Uang Beredar. Otoritas Moneter (bank sentral) dan bank bank umum adalah lembaga yang dapat menciptakan uang. Bank sentral mengeluarkan dan mengedarkan uang kartal sedangkan bank umum mengeluarkan dan mengedarkan uang giral dan uang kuasi. Semua uang yang dikeluarkan dan diedarkan merupakan kewajiban lembaga yang mengeluarkan dan mengedarkannya. Satu bank umum mempunyai kewajiban uang giral sebesar rekening giro yang disimpan masyarakat dan ditambah dengan kewajiban uang kuasi sebesar tabungan dan deposito berjangka yang disimpan masyarakat pada bank umum yang bersangkutan.

Dengan mengeluarkan dan mengedarkan uang berarti sistim moneter mempunyai kewajiban kepada sektor swasta domestik atau penduduk / masyarakat baik individu, badan usaha dan lembaga lainnya. Oleh karena itu uang beredar itu didefinisikan sebagai kewajiban sistem moneter terhadap sektor swasta domestik (Suseno, 2005)

Uang beredar di Indonesia terdiri dari dua macam seperti yang dimuat dalam Statistik Ekonomi dan Keuangan Indonesia yang dikeluarkan oleh Bank Indonesia yaitu, uang beredar dalam arti sempit, yang sering diberi simbol sebagai M1, didefinisikan sebagai kewajiban sistem moneter terhadap sektor swasta domestik yang terdiri dari uang kartal dan uang giral, dan uang beredar dalam arti luas, yang sering juga disebut sebagai likuiditas perekonomian dan diberi simbol M2 didefinisikan sebagai kewajiaban sistem moneter terhadap sektor swasta domestik yang terdiri dari uang kartal, uang giral dan uang kuasi, atau dengan kata lain M2 adalah M1 ditrambah uang kuasi.

Nilai Tukar Perdagangan Luar Negeri. Sumberdaya yang akan dipergunakan untuk menghasilkan barang barang tidak semuanya dapat diperoleh di dalam negeri, untuk itu diperlukan adanya perdagangan antar negara. Perdagangan internasional selalu memperhatikan perkembangan harga - harga relatif dari ekspor dan impor yang disebut "terms of trade". Terms of Trade atau nilai tukar perdagangan ini memperlihatkan suatu perbandingan antara tingkat harga ekspor dengan tingkat harga impor. Perubahan perubahan dalam harga eskpor ataupun harga impor sangat berpengaruh terhadap terms of trade suatu negara.

Nilai tukar perdagangan suatu negara dapat dilihat dalam beberapa konsep (Nopirin, 1999), tetapi dua konsep yang penting dan sering digunakan adalah (1). Commodity Terms of Trade atau Net Barter Terms of Trade dan (2) Income Terms of Trade

Kedua bentuk nilai tukar tersebut dapat dihitung dengan menggunakan rumus rumus sebagai berikut:

$$
\begin{aligned}
& \text { NT }=\frac{\text { PX }}{\text { PM }} \text { X } 100 \\
& \text { PX }=\underset{\text { PM }}{\text { PX }}
\end{aligned}
$$

Dimana :

$\mathrm{NT}=$ Net barter terms of trade, yang sering disingkat dengan terms of trade; $\mathrm{PX}=$ Indeks harga ekspor; $\mathrm{PM}=$ Indeks harga Impor; IT = Income term of trade; $\mathrm{QT}=$ Indeks volume Eskpor

Dari Net barter terms of trdae (NT) tersebut dapat dikemukakan bahwa suatu kenaikan dalam NT berarti dengan suatu jumlah volume tertentu dalam perdagangan akan dapat memperoleh jumlah volume impor yang lebih besar. Sedangkan kenaikan dalam 
Income terms of tarde of trade (IT) menunjukkan bahwa suatu negara akan dapat memperoleh jumlah volume yang lebih besar dari hasil penjualan ekspor, ini berarti "kapasitas mengimpor" yang didasarkan atas ekspornya telah meningkat. Dari kedua konsep ini tersebut, konsep net barter terms of tarde lebih sering dipakai karena lebih mudah dimengerti. Seandainya harga impor relatif lebih besar kenaikannya dari pada harga ekspor, nilai tukar perdagangan akan memburuk. Akibatnya, untuk memperoleh nilai impor yang sama seperti waktu lampau, volume eskpor juga harus lebih besar dari pada aktu yang lampau. Ini berarti pula negara tersebut mengalami kemunduran kapasitas impor.

Kaitan antar variabel. Hubungan Antara Inflasi Dengan Jumlah Uang Beredar. Hubungan antara inflasi dan jumlah uang beredar didasari oleh teori kuantitas uang, sedangkan nilai uang ditentukan oleh permintaan dan penawaran terhadap uang. Adapun jumlah uang beredar ditentukan oleh kebijakan bank sentral selaku otoritas moneter. Jumlah uang yang diminta (money demand) ditentukan oleh berbagai faktor antara lain tingkat harga rata rata dalam perekonomian, sehingga keinginan masyarakat memegang uang tunai untuk melakukan transaksi tergantung kepada tingkat harga barang dan jasa yang dihasilkan oleh perekonomian. Jika harga semakin tinggi maka semakin besar pula jumlah uang yang akan diminta masyarakat.

Kebijakan bank sentral untuk menambah jumlah uang beredar misalnya dengan mencetak lebih banyak uang akan menyebabkan keseimbangan antara permintaan uang dan penawaran uang akan berubah. Menurut teori moneter Keynes kebijakan ini cenderung menurunkan tingkat suku bunga, sehingga masyarakat lebih memilih untuk menarik uang mereka dan memegangnya dalam bentuk uang tunai. Ketika masyarakat memegang uang tunai dalam jumlah yang lebih banyak terjadilah ketidakseimbangan dalam perekonomian yang akan memicu kenaikan harga. Penyebabnya adalah jumlah barang yang diminta sudah jauh melebihi dari jumlah barang dan jasa yang dihasilkan perekonomian sebagai dampak kenaikan jumlah uang beredar tersebut.

Hubungan Antara Inflasi Dengan Nilai Tukar Perdagangan Luar Negeri. Nilai tukar pedagangan luar negeri menggambarkan kemampuan suatu negara untuk mengimpor dari luar negeri yang diukur dengan kemampuan ekspor negara tersebut. Nilai tukar perdagangan luar negeri yang makin baik menunjukkan bahwa kapasitas mengimpor akan menjadi lebih baik, artinya, untuk mengimpor sejumlah tertentu dapat dilakukan dengan jumlah atau volume ekspor yang lebih sedikit dari kondisi sebelumnya. Hal ini mengindikasikan bahwa harga harga barang impor secara relatif nilainya mengalami penurunan atau lebih murah dibandingkan dengan harga barang barang yang di ekspor pada periode tersebut.

Kondisi yang sebaliknya akan terjadi apabila nilai tukar perdagangan luar negeri semakin memburuk yang menandakan bahwa harga relatif barang barang yang diimpor jauh lebih mahal dari pada harga barang barang yang diekspor. Oleh karena itu untuk mendapat sejumlah barang impor yang sama kita membutuhkan ekspor yang lebih besar. Dampaknya terhadap inflasi didalam negeri adalah bahwa, nilai tukar perdangan yang makin membaik akan dapat menahan laju kenaikan harga di dalam negeri terutama dapat menghambat naiknya harga impor barang - barang konsumsi maupun barang modal. Demikian juga sebaliknya memburuknya nilai tukar perdagangan luar negeri membawa konsekuensi kenaikan harga di dalam negeri, terutama harga barang modal dan bahan 
baku yang diimpor dari luar negeri. Hal ini menyebabkan kenaikan biaya produksi dan menyebabkan cost push inflation.

(Sofilda dan Sutarno, 2007) menyatakan bahwa tingkat inflasi yang tinggi di Indonesia akibat kebijakan ekonomi makro yang tidak konsisten, sehingga inflsi sulit di kendalikan. Hasil penelitian yang menggunakan pendekatan kointegrasi dan model koreksi kesalahan atau error correction model (ECM) menyimpulkan bahwa untuk jangka panjang, nilai tukar rupiah terhadap dollar Amerika memperlihatkan pengaruh positif tetapi tidak signifikan. Sementara itu untuk jangka pendek perubahan jumlah uang beredar dan pengeluaran pemerintah memberikan pengaruh yang tidak signifikan. Adapun nilai tukar rupiah terhadap Dollar Amerika berpengaruh siginifikan.

Penelitian lainnya dilakukan oleh (Agung dan Warjiyo, 2003) dengan memasukkan variabel - variabel indikator dan satu faktor variabel kontrol. Kesimpulan yang diperoleh dari penelitian ini adalah variabel nilai tukar merupakan "the best indicator" inflasi dan memberikan efek yang segera terhadap inflasi. Variabel kuantitas uang seperti uang kartal, (base money) M1 dan M2 memiliki kandungan informasi yang cukup tinggi terhadap inflasi, namun kandungan informasi agregat moneter ini melemah ketika nilai tukar dimasukkan sebagai variabel kontrol

Hasil Penelitian (Atmadja, 1999) menyatakan bahwa inflasi di Indonesai buka semata mata hanya disebabkan oleh gagalnya pelaksanaan kebijakan di sektor moneter oleh pemerintah yang sering kali dilakukan untuk tujuan menstabilkan fluktuasi tingkat harga umum dalam jangka pendek, tetapi juga mengindikasikan masih adanya hambatan hambatan struktural dalam perekonomian Indonesia yang belum sepenuhnya dapat diatasi

Penelitian yang dilakukan oleh (Sutawijaya dan Zulfahmi, 2012) dengan menggunakan data antara tahun 1985 hingga 2005 dengan pendekatan OLS (Ordinary Least Square) menyatakan bahwa tingkat suku bunga, jumlah uang beredar, investasi dan nilai tukar secara simultan mempengaruhi inflasi di Indonesia. Secara parsial faktor tingkat sukubunga mempunyai pengaruh positif terhadap inflasi, demikian juga halnya dengan jumlah uang beredar yang juga mempunyai hubungan positif dengan inflasi. Adapun variabel investasi memberikan pengaruh yang negatif terhadap inflasi, sedangkan variabel nilai tukar rupiah terhadap dollar AS memberikan pengaruh negatif.

Penelitian (Maulida et al., 2010) menyimpulkan terdapat pengaruh yang cukup signifikan antara defisit anggaran pemerintah, jumlah uang beredar dan independensi Bank Indonesia terhadap Inflasi di Indonesia.

Penelitian yang dilakukan di Pakistan oleh (Sajjad dan Iqbal, 2011) tentang pengaruh jumlah uang beredar terhadap tingkat inflasi menyatakan bahwa tingkat inflasi sangat dipengaruhi oleh jumlah uang beredar dan kondisi itu menyebabkan dampak negatif terhadap pembangunan ekonomi di negara tersebut.

(Hove et al., 2012) meneliti guncangan dalam nilai tukar perdagangan luar negeri dikaitkan dengan target inflasi dengan menggunakan data panel pada 35 negara yang menganut sistem perekonomian pasar yang berkembang selama periode tahun 1980 sampai tahun 2008 menyimpulkan bahwa negara negara yang tidak memperhitungkan guncangan nilai tukar perdagangan (terms of trade shocks) ke dalam target inflasinya akan mengalami variasi yang relatif lebih tinggi dibandingkan dengan negara negara yang mengadopsi guncangan nilai tukar perdagangan kedalam target inflasi mereka.

Menurut (Colleti dan Lalonde, 2008) kebijakan penetapan target inflasi masih mempunyai kekurangan karena tidak menentukan kepastian tingkat harga dalam perekonomian dimasa mendatang. Target tingkat harga (Price Level Targeting/PLT) akan 
dapat mengurangi ketidakpastian dimasa depan baik yang disebabkan oleh peningkatan biaya akibat ketidakstabilan ekonomi makro, termasuk faktor faktor yang berasal dari fluktuasi nilai tukar perdagangan di negara Canada.

(Gruen dan Dwyer, 1995) mencoba membuat sebuah model bagaimana hubungan nilai tukar perdagangan terhadap inflasi. Hasil temuannya menunjukkan, baik secara analitis dan empiris, bahwa respon nilai tukar mata uang (kurs) terhadap perubahan dalam nilai tukar perdagangan sangat berpengaruh terhadap tingkat inflasi. Penelitiannya juga menunjukkan adanya 'batas' respon nilai tukar (kurs). Perubahan nilai tukar mata uang akan membawa dampak terhadap nilai tukar perdagangan luar negeri.

(Patnaik, 2010) meneliti tentang inflasi di India dengan menggunakan indek harga konsumen sebagai independen variabel dan tiga dependen variabel masing masing adalah adalah indeks produksi industri, yang merepresentasikan jumlah permintaan dalam perekonomian, reserve money yang merepresentasikan jumlah uang beredar dalam perekonomian dan indeks impor, untuk melihat pengaruh eksternal terhadap harga domestik. Kesimpulan dari penelitiannya menunjukkan bahwa ketiga variabel tersebut secara signifikan mempengaruhi Inflasi di India.

Hipotesis. Perumusan hipotesis ini ditujukan memberikan arah dan pedoman dalam melakukan penelitian. Hipotesis yang digunakan dalam penelitian ini sebagai berikut:

1. Jumlah uang beredar pada periode periode sebelumnya ( $t-1)$ mempunyai pengaruh positif terhadap indek harga konsumen pada tahun berjalan $(\mathrm{t})$

2. Nilai Tukar Perdagangan Luar Negerti ( NT ) mempunyai pengaruh negatif dan signifikan terhadap Inflasi yang direpresentasikan oleh indeks harga konsumen

3. Indek harga konsumen periode yang lalu akan mempengaruhi indeks harga konsumen pada periode sekarang .

\section{METODE}

Untuk mengetahui bagaimana hubungan atau berapa besar pengaruh jumlah uang beredar dan nilai tukar perdagangan luar negeri terhadap tingkat harga umum, maka penelitian ini akan menggunakan model berdistribusi beda kala (distributed lag models). Disini terdapat selang waktu penyesuaian jumlah uang beredar dengan perkembangan tingkat harga. Dengan memasukkan variabel time lag ini diharapkan dapat lebih menjelaskan bentuk hubungan jumlah uang beredar ini terhadap tingkat harga umum. Sesuai dengan kerangka teori dan paradigma penelitian dalam penelitian ini dapat diturunkan model / persamaan regresi sebagai berikut:

$$
\mathrm{IHK}_{\mathrm{t}}=\mathrm{f}\left(\mathrm{JUB}_{\mathrm{t}}, \mathrm{JUB}_{\mathrm{t}-1}, \mathrm{NT}_{\mathrm{t}}, \varepsilon\right)
$$

Dimana: $\mathrm{IHK}_{\mathrm{t}}=$ Indeks harga Konsumen pada periode $\mathrm{t} ; \mathrm{JUB}_{\mathrm{t}}=$ Jumlah uang beredar pada periode $\mathrm{t}$; JUB ${ }_{\mathrm{t}-1}=$ Jumlah uang beredar pada perode $\mathrm{t}-; \mathrm{NTP}_{\mathrm{t}}=$ Nilai Tukar Perdagangan Luar Negeri peride $t ; \varepsilon=$ Kesalahan, error dari model

Untuk mengetahui nilai parameter dari variabel variabel yang menentukan perkembangan tingkat harga tersebut diatas maka model tersebut ditransformasikan kedalam bentuk persamaan sebagai berikut :

$$
\mathrm{IHK}_{\mathrm{t}}=\mathrm{b}_{0}+\mathrm{b}_{1} \mathrm{JUB}_{\mathrm{t}}+\mathrm{b}_{2} \mathrm{JUB}_{\mathrm{t}-1}+\mathrm{b}_{3} \mathrm{NT}_{\mathrm{t}}+\varepsilon
$$

Dimana: $b_{o}$,adalah nilai konstanta dari model; $b_{1} \ldots . b_{3}$, adalah koefisien regresi dari model; $\varepsilon$, adalah Kesalahan ( error ) dari model. 
Disamping itu, untuk mengetahui tingkat harga umum yang dibutuhkan untuk mencapai tingkat pertumbuhan ekonomi yang optimum, tanpa menimbulkan ketidakseimbangan, dianggap bahwa tingkat harga umum yang diinginkan merupakan fungsi linier dari jumlah uang beredar tahun berjalan dan tahun lalu serta nilai tukar perdagangan tahun berjalan atau:

Dimana:

$$
\mathrm{IHK}_{\mathrm{t}}=\mathrm{a}+\mathrm{b}_{1} \mathrm{JUB}_{\mathrm{t}}+\mathrm{b}_{2} \mathrm{JUB}_{\mathrm{t}-1}+\mathrm{b}_{3} \mathrm{NT}_{\mathrm{t}}+\varepsilon
$$

$\mathrm{IHK}_{\mathrm{t}}=$ Indeks harga Konsumen yang diinginkan pada periode $\mathrm{t} ; \mathrm{JUB}_{\mathrm{t}}=$ Jumlah uang beredar pada periode $\mathrm{t}$; JUB $\mathrm{t}_{\mathrm{t}-1}=$ Jumlah uang beredar pada perode $\mathrm{t}-1 ; \mathrm{NTP}_{\mathrm{t}}=$ Nilai Tukar Perdagangan Luar Negeri peride t; $\varepsilon=$ Kesalahan, error dari model

Karena perubahan tingkat harga yang diinginkan baik oleh pemerintah maupun oleh masyarakat tidak dapat diketahui secara langsung, maka digunakan metode yang dikembangkan oleh Marc Nerlove, yang dikenal dengan metode penyesuaian parsial ( partial adjustment hypotesis ) seperti berikut: (Gujarati 2003)

dimana:

$$
\mathrm{IHK}_{\mathrm{t}}-\mathrm{IHK}_{\mathrm{t}-1}=\mathrm{s}\left(\mathrm{IHK}_{\mathrm{t}}-\mathrm{IHK}_{\mathrm{t}-1}\right)
$$

$0<\mathrm{s}<1$ adalah merupakan koefisien penyesuaian parsial; $\mathrm{IHK}_{\mathrm{t}}-\mathrm{IHK}_{\mathrm{t}-1}=$ perubahan harga actual; $\mathrm{IHK}^{*}-\mathrm{IHK}_{\mathrm{t}-1}=$ perubahan tingkat harga yang diharapkan

Persamaan (4) diatas memperlihatkan bahwa perubahan tingkat harga dalam periode tertentu merupakan fraksi $s$ dari perubahan tingkat harga yang diinginkan untuk periode tersebut. Jika $s=1$ maka berarti tingkat harga aktual sama dengan tingkat harga yang diinginkan yang merupakan tingkat harga aktual yang meneyesuaikan diri dengan segera dalam periode yang sama. Akan tetapi jika $s=0$ berarti tidak terjadi perubahan harga karena tingkat harga aktual sama dengan tahun yang sebelumnya (Gujarati)

Metode penyesuaian seperti pada persamaan (4) bisa juga ditulis dalam bentuk persamaan sebagai berikut

$$
\mathrm{IHK}_{\mathrm{t}}=\mathrm{IHK}_{\mathrm{t}}+(1-\mathrm{s}) \mathrm{IHK}_{\mathrm{t}-1}
$$

Persamaan (5) ini menunjukkan bahwa tingkat harga yang diamati pada periode $t$ adalah rata rata tertimbang (weighted average) dari tingkat harga yang diinginkan pada periode tersebut dengan tingkat harga pada tahun sebelumnya, dengan $\boldsymbol{s}$ dan $(\boldsymbol{1}-\boldsymbol{s})$ merupakan bobot ( weight ). Sekarang dengan mensubstitusikan persamaan (3) ke dalam persamaan (5) akan diperoleh:

$\mathrm{IHKt}=\mathrm{s}\left(\mathrm{b} 0+\mathrm{b}_{1} \mathrm{JUB}_{\mathrm{t}}+\mathrm{b}_{2} \mathrm{JUB}_{\mathrm{t}-1}+\mathrm{b}_{3} \mathrm{NT}_{\mathrm{t}}+\varepsilon\right)+(1-\mathrm{s}) \mathrm{IHK}_{\mathrm{t}-1}$

$\mathrm{IHKt}=\mathrm{s} b 0+\mathrm{sb}_{1} \mathrm{JUB}_{\mathrm{t}}+\mathrm{sb}_{2} \mathrm{JUB}_{\mathrm{t}-1}+\mathrm{sb}_{3} \mathrm{NT}_{\mathrm{t}}+(1-\mathrm{s}) \mathrm{IHKt}-1+\mathrm{s} \varepsilon$

Untuk selanjutnya persamaan (6) tersebut yang digunakan dalam menganalisa perkembangan tingkat harga, jumlah uang beredar dan nilai tukar pedagangan di Indonesia.

\section{HASIL DAN PEMBAHASAN}

Dalam bagian berikut ini akan diperlihatkan hasil pengujian dan perkiraan hubungan antara perkembangan tingkat harga dengan jumlah uang beredar dengan menggunakan metode ordinary least square (OLS) dengan alat pengolah data Eviews. Didasarkan kepada hasil perhitungan yang sudah dilakukan untuk persamaan seperti yang telah 
dispesifikasikan pada persamaan (6), maka kita akan mendapatkan suatu struktur perkembangan tingkat harga di Indonesia, hasil regresi menunjukkan, semua variabel yang relevan koefiseien regresinya mempunyai nilai dan arah yang sesuai dengan hipotesa, akan tetapi ternyata variabel JUB, dan JUBt-1 tidaklah signifikan secara statistik. Hal terlihat dari nilai $t$ hitung (statistik $t$ ) yang yang nilainya lebih kecil dari nilai statistik $t$ dalam tabel.

Oleh karena itu dicoba untuk membuat estimasi dengan alternatif yang lain lain, yaitu dengan mengeluarkan salah satu variabel bebas yaitu JUB t-1, namun dari koefisien regresi yang diperoleh meskipun arah dan nilainya sudah sesuai dengan hipotesa, ternyata masih terdapat variabel yang tidak signifikan yaitu Nilai Tukar (NT). Hal ini terlihat dari rendahnya nilai hitung stastistik t jika dibandingkan dengan nilai t statistik dalam tabel. Alternatif berikutnya yang dilakukan adalah dengan mencoba mengeluarkan variabel JUB dari persamaan regressi tersebut. Hasil oleh data tersebut disajikan dalam regressi yang disajikan dalam Tabel 1 berikut ini:

Dependent Variable: IHK

Tabel 1. Hasil Regresi Eviews

Method: Least Squares

Date: 07/09/14 Time: 14:57

Sample (adjusted): 19912012

Included observations: 22 after adjustments

\begin{tabular}{lrcrr}
\hline \hline \multicolumn{1}{c}{ Variable } & Coefficient & Std. Error & t-Statistic & Prob. \\
\hline \hline \multicolumn{1}{c}{ C } & -225.7209 & 79.43212 & -2.841683 & 0.0108 \\
LOG(JUBT_1) & 23.61821 & 8.174262 & 2.889339 & 0.0098 \\
$\quad$ NT & -0.105987 & 0.091580 & -1.157311 & 0.2623 \\
\multicolumn{1}{c}{ IHKT_1 } & 0.672710 & 0.126051 & 5.336806 & 0.0000 \\
\hline \hline R-squared & 0.990745 & Mean dependent var & 122.7086 \\
Adjusted R- & & & \\
squared & 0.989202 & S.D. dependent var & 72.70962 \\
S.E. of & & & \\
regression & 7.555451 & Akaike info criterion & 7.045381 \\
Sum squared & & & \\
resid & 1027.527 & Schwarz criterion & 7.243753 \\
Log likelihood & -73.49919 & Hannan-Quinn criter. & 7.092112 \\
F-statistic & 642.2777 & Durbin-Watson stat & 2.311916 \\
Prob(F-statistic) & 0.000000 & & \\
\hline \hline
\end{tabular}

Jika hasil regressi pada Tabel 2 diatas dimasukkan ke dalam model maka akan diperoleh persamaan sebagai berikut:

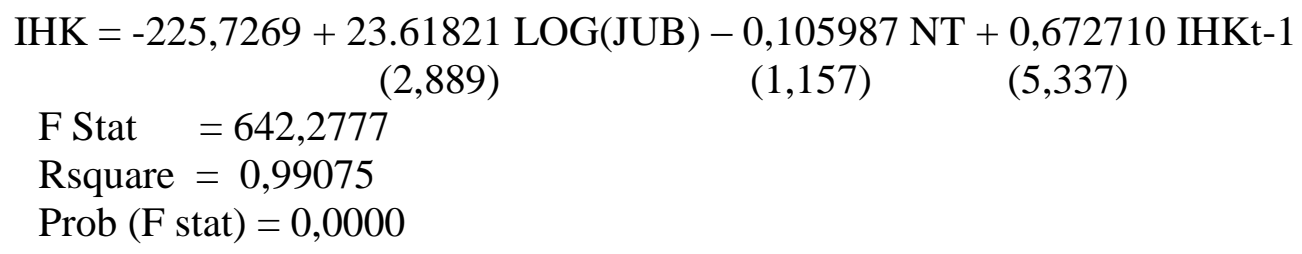


Dari hasil olah data pada tabel 1 diatas dapat dilihat bahwa semua variabel yang digunakan dalam penelitian ini memberikan arah koefisien regresi yang sesuai dengan hipotesa dan signifikan secara statistik, karena mempunyai nilai t statistik yang lebih besar dari statistik t tabel.

Pengujian Asumsi Klasik. Asumsi Homokedastistitas. Untuk mendeteksi adanya heteroskedastisitas dapat menggunakan uji Glejser Heteroskedasticity Test.

Tabel 2. Hasil Uji Glejser

Heteroskedasticity Test: Glejser

\begin{tabular}{llll}
\hline \hline F-statistic & 4.591556 & Prob. F(3,18) & 0.0148 \\
Obs*R-squared & 9.537242 & Prob. Chi-Square(3) & 0.0229 \\
Scaled explained SS & 10.08937 & Prob. Chi-Square(3) & 0.0178 \\
\hline \hline
\end{tabular}

Test Equation:

Dependent Variable: ARESID

Method: Least Squares

Date: 07/09/14 Time: $16: 55$

Sample: 19912012

Included observations: 22

\begin{tabular}{lrlll}
\hline \hline \multicolumn{1}{c}{ Variable } & Coefficient & Std. Error & t-Statistic & Prob. \\
\hline \hline \multicolumn{1}{c}{ C } & -116.5247 & 40.97965 & -2.843478 & 0.0108 \\
LOG(JUBT_1) & 12.94739 & 4.217166 & 3.070165 & 0.0066 \\
$\quad$ NT & -0.100575 & 0.047247 & -2.128700 & 0.0473 \\
$\quad$ IHKT_1 & -0.221086 & 0.065031 & -3.399710 & 0.0032 \\
\hline \hline R-squared & 0.433511 & Mean dependent var & 4.976082 \\
Adjusted R-squared & 0.339096 & S.D. dependent var & 4.794721 \\
S.E. of regression & 3.897916 & Akaike info criterion & 5.721727 \\
Sum squared resid & 273.4875 & Schwarz criterion & 5.920098 \\
Log likelihood & -58.93900 & Hannan-Quinn criter. & 5.768457 \\
F-statistic & 4.591556 & Durbin-Watson stat & 1.527838 \\
Prob(F-statistic) & 0.014803 & & \\
\hline \hline
\end{tabular}

Kriteria yang digunakan untuk uji Glejser ini adalah jika koefisien varibel independen tidak signifikan maka disimpulkan bahwa terdapat heteroskedastisitas, sebaliknya jika keofisien variabel independen nya signifikan maka disimpulkan tidak terjadi heteroskedasitas. Hasil uji Glejser disajikan dalam tabel 2. Dari tabel tersebut dapat diketahui bahwa, pada persamaan regresi tersebut tidak ditemukan adanya heteroskedastisitas. Hal ini dapat diketahui dari signifikannya semua koefisien variabel independen. Hal ini terlihat dari nailai hitung statistik t, untuk semua varabelnya lebih besar dari statistik t dalam tabel, masing masing adalah 3,070 untuk variabel JUBt-1, 2,129 untuk NT dan -3,399 untuk IHKt-1

Asumsi Autokorelasi . Untuk mendeteksi adanya korelasi serial adalah dengan melihat nilai $d$ yang merupakan koefisien Durbin Watson $(D W)$. Nilai $d$ itu akan berada pada kisaran 0 hingga 4 .Untuk mengetahui ada/tidaknya autokorelasi menurut Winarno\{ 2011), dapat digunakan panduan berikut : Apabila $d$ berada diantara 1,54 dan 2,46, maka 
tidak ada autokorelasi dan apabila nilai d ada diantara 0 hingga 1,10 dapat disimpulkan bahwa data mengandung auotokorelasi positif :

Dari hasil pengolahan pada tabel 4 untuk persamaan (1) dapat dilihat besarnya Durbin - Watson ( DW ) sebesar 2,3119. Nilai ini terletak antar 1,54 dengan 2,46, yang berarti dalam model ini tidak terdapat kasus autokorelasi.

\section{Analisis Hasil Regresi}

Berdasarkan hasil pengolahan data dengan Eviews diperoleh persamaan hasil regresi untuk mengetahui pengaruh jumlah uang beredar (JUB) dan nilai tukar perdagangan (NT) terhadap inflasi yang dalam hal ini direpresentasikan oleh data indeks harga konsumen (IHK).

Persamaan hasil regresinya adalah sbb :

$\begin{array}{llccc}\text { IHK }= & -225,7269+23,61821 & \text { LOG }(J U B) & -0,105987 \mathrm{NT}+0,672710 \mathrm{IHKt}-1 \\ \mathrm{SE} & (79.43212) & (8.174262) & (0.091580) & (0.126051) \\ \mathrm{t} \text { test } & (-2.841683) & (2.889339) & (-1.157311) & (5.336806)\end{array}$

Rsquare $=0.990745$

$(-1.157311) \quad(5.336806)$

F Stat $=642,2777$

Prob $($ F stat $)=0,000000$

Uji F. Pengujian ini dilakukan untuk mengetahui apakah variabel bebas jumlah uang beredar (JUB), nilai tukar perdagangan luar negeri (NT) dan Indeks harga konsumen tahun sebelumnya (IHKt-1) secara bersama sama mempengaruhi variabel terikat indek harga konsumen (IHK). Dari hasil pengolahan data diatas diperoleh nilai statistik $\mathrm{F}$ sebesar 642,2777 dengan probabilitas 0,000000. Nilai probabilitas ini lebih kecil dari 5\% yang berarti bahwa model diatas dapat menjelaskan bahwa Jumlah uang beredar (JUB), Nilai Tukar Perdagangan (NT) dan Indeks Harga Konsumen periode sebelumnya secara bersama - sama berpengaruh terhadap Inflasi yang direpresentasikan oleh Indeks Harga Konsumen.

Uji t. Pengujian hipotesis dengan menggunakan Uji Statistik $\mathrm{t}$ ( $t$ test ) digunakan untuk menguji signifikansi dari variabel bebas terhadap variabel terikat secara parsial atau individu. Berdasarkan hasil pengolahan data pada tabel 1 dapat disimpulkan bahwa ternyata Jumlah Uang Beredar (JUB), dan Indeks Harga Konsumen periode sebelumnya (IHKt-1) secara statistik signifikan mempengaruhi inflasi yang direpresentasikan oleh Indeks Harga Konsumen (IHK). Hal ini ditunjukkan oleh nilai probabilitas ( $p$ value ) untuk masing masing variabel tersebut lebih kecil dari $5 \%$. Nilai probabilitas ( $p$ value) untuk variabel jumlah uang beredar (JUB) adalah 0,0098 dan $\mathrm{p}$ value untuk variabel IHKt1 adalah 0,000. Adapun variabel Nilai Tukar Perdagangan (NT) secara statistik tidak signifikan mempengaruhi Inflasi karena nilai $\mathrm{p}$ valuenya adalah 0,2623 yang lebih besar dari $5 \%$.

Koefisien Determinasi $\left(\mathbf{R}^{2}\right)$. Koefisien determinasi $\left(\mathbf{R}^{2}\right)$ dari persamaan (1) diatas adalah sebesar $=0.990745$, yang berarti lebih kurang 99,07 \% variasi perubahan Inflasi yang direpresentasikan oleh Indeks Harga Konsumen ditentukan / dipengaruhi oleh variasi perubahan Jumlah Uang Beredar (JUB), Nilai Tukar Perdagangan (NT) dan Indeks Harga Konsumen periode sebelumnya (IHKt-1), adapun pengaruh variabel lain diluar model ini hanya $0,0093 \%$. 
Sekalipun secara statistik model diatas dapat digunakan untuk melakukan prediksi, namun pengujian dengan teori yang ada perlu dilakukan, agar model akan semakin valid untuk digunakan sebagat alat prediksi.

Setelah dilakukan beberapa pengujian yang diperlukan dalam menganalisis persamaan diatas dapat diambil beberapa kesimpulan umum sebagai berikut:

1. Setiap terjadi pertambahan jumlah uang beredar sebesar 1 persen akan dapat meningkatkan Indeks Harga Konsumen sebesar 23,63 unit, atau sebaliknya. Hal ini menunjukan adanya hubungan positif / searah antara jumlah uang beredar dengan tingkat harga. Hasil sejalan dengan hasil penelitian sebelumnya yang dilakukan oleh (Sofilda dan Sutarno, 2007), (Sutawijaya dan Zulfahmi, 2012), (Mardiana dan Mayes, 2010), dan (Sajjad dan Iqbal, 2011)

2. Pengaruh perubahan nilai tukar perdagangan terhadap indeks harga konsumen sejalan dengan teori yaitu mempunyai hubungan negatif. Menurunnya nilai tukar perdagangan luar negeri sebesar 1 unit akan menaikkan indeks harga konsumen sebesar 0,105987 unit dan sebaliknya. Penelitian yang dilakukan oleh (Gruen dan Dwyer, 1995) juga menyatakan adanya pengaruh nilai tukar perdagangan terhadap inflasi. Sementara itu (Hove et al., 2012) menyarankan pentingnya memasukkan nilai tukar perdagangan ini ke dalam target inflasi.

3. Koefisien penyesuaian parsial sebesar $s=(1-0,672710)=0,32729$ pada model diatas menujukkan bahwa 32,73 \% penyesuaian antara tingkat harga umum yang diinginkan dengan tingkat harga umum yang sebenarnya (tingkat harga umum aktual) berlangsung dalam jangka waktu satu tahun.

Dari hasil estimasi pada model diatas, yang sekaligus juga merupakan persamaan struktur tingkat harga umum dalam jangka pendek, dapat diperoleh bentuk persamaan tingkat harga umum jangka panjang dengan membagi persamaan tingkat harga umum jangka pendek tersebut dengan nilai koefisien penyesuaian parsial (s) dan mengenyampingkan variabel IHKt-1. Sehubungan dengan itu diperoleh persamaan tingkat harga umum dalam jangka panjang sebagai berikut:

$$
\mathrm{IHK}^{*}=-698,6847+72,1629 \mathrm{JUBt}-1+0,32383 \mathrm{NT}
$$

Dari persamaan diatas terlihat bahwa pengaruh perubahan jumlah uang beredar (JUB) dalam jangka panjang mengalami kenaikan dibandingkan dengan jangka pendek. Hal yang sama juga terlihat dalam pengaruh perubahan nikai tukar perdangan terhadap tingkat harga umum yang juga lebih besar dari yang sebelumnya.

\section{PENUTUP}

Dari hasil penelitian ini dapat diperoleh beberapa kesimpulan penting diantaranya adalah:

Terdapat pengaruh yang signifikan dan positif antara jumlah uang beredar periode sebelumnya terhadap inflasi yang direpresentaskan oleh indeks harga konsumen pada tahun yang sedang berjalan.

Nilai Tukar Perdagangan luar negeri (NT) mempunyai hubungan negatif dengan perkembangan tingkat harga atau inflasi. Nilai tukar yang semakin menurun atau memburuk akan menyebabkan naiknya inflasi yang dalam hal ini ditunjukkan oleh kenaikan indeks harga konsumen. Akan tetapi dalam penelitian ini pengaruhnya tersebut tidaklah signifikan secara statsitstik. 
Dalam jangka panjang ternyata pengaruh jumlah uang berdar terhadap inflasi dan perkembangan harga lebih besar dibandingkan dalam jangka pendek.

Untuk lebih menyempurnakan penelitian ini dimasa mendatang disarankan untuk menambahkan variabel - variabel lainnya dalam penelitian ini. Adapun dalam penentuan nilai tukar perdagangan luar negeri disarankan ntuk membedakan antara migas dan non migas serta nilai tukar menurut menurut kelompok barang untuk lebih melihat dampaknya terhadap inflasi dan perkembangan harga.

\section{DAFTAR RUJUKAN}

Boediono (2009). Ekonomi Moneter, Seri Sinopsis Pengantar Ilmu Ekonomi No 5 Yogyakarta : BPFE.

Colleti Donald and Lalonde Rene (2008). "Inflation Targeting, Price Level Targeting, and Fluctuation in Canada's Terms of Trade", Bank of Canada Reviews , Winter 20072008.

Dornbusch, Rudiger, Fischer Stanley, Starzt Richard, (2004). Makroekonomi edisi 8, alih Bahasa Yusuf Wibisono dan Roy Indra Mirazudin, Media Global Edukasi.

Gruen David and Dwyer Jacqueline (1995). “Are Terms of Trade Rises Inflationary?", Research Discussion Paper 9508, Economic Research Departemen Reserve Bank of Australia.

Gujarati, Damodar N. (2003). Basic Econometrics, Fourth Edition, McGraw Hill International Edition.

Hove, Seedwell, Mama Albert Touna and Tchana Fulbert (2012). Terms of Trade Shocks and Inflation Targeting in Emerging Market Economies, Working Paper no 273 Finance Quebec.

Mankiw, N Gregory, (2000). Teori Makro Ekonomi, edisi 4 Alih Bahasa oleh Imam Nurmawan, Jakarta Erlangga.

Mangkoesubroto,Guritno dan Algifari (1998). Teori Ekonomi Makro, Yogyakarta STIE YKPN.

Maulida Yusni, Mardiana dan Mayes Anthoni (2010). Pengaruh Defisit Anggaran, Jumlah uang Beredar dan Independensi Bank Indonesia terhadap Inflasi, Hasil Penelitian FE Universitas Riau, Pekanbaru (tidak diterbitkan).

Nopirin (2000). Ekonomi Moneter Buku II, Yogyakarta BPFE.

Nopirin (1999). Ekonomi Internasional, edisi 3, Yogyakarta BPFE.

Patnaik, Anuradha, (2010). "Study of Inflation in India: A Cointegrated Vector Autoregression Approach", Jurnal of Quantitative Economics, 8 (1).

Riduwan dan Engkos Achmad Kuncoro (2008). Cara Menggunakan dan Memaknai Analisis Jalur ( Path Analysis ), Bandung Alfabeta.

Sajjad,Gul dan Hassan, Iqbal (2011). "The Impact of money supply on Inflation in Pakistan", Interdisciplinary Journal of Countemporary Research in Bussines, 3 (8).

Samuelson Paul. A \& Nordhaus William D (2005). Economics, eighteenth edition Mc Graw Hill Companies Inc.

Sukirno, Sadono (2004). Makroekonomi Teori Pengantar, Rajagrafindo Persada.

Seseno, Solikin (2005). Uang, Pengertian, Penciptaan dan Peranannya dalam Perekonomian, Seri Kebanksentralan Bank Indonesia.

Sutawijaya, Adrian dan Zulfahmi (2012). "Pengaruh Faktor-Faktor Ekonomi Terhadap Inflasi di Indonesia", Jurnal Organisasi dan Manajemen, 8 (2). 
